\title{
SMAD4 - Molecular gladiator of the TGF- $\beta$ signaling is trampled upon by mutational insufficiency in colorectal carcinoma of Kashmiri population: an analysis with relation to KRAS proto-oncogene
}

\author{
A Syed Sameer ${ }^{1,2,3}$, Nissar A Chowdri ${ }^{3}$, Nidda Syeed ${ }^{+1}$, Mujeeb Z Banday ${ }^{\dagger 4}$, Zaffar A Shah and Mushtaq A Siddiqi*1
}

\begin{abstract}
Background: The development and progression of colorectal cancer has been extensively studied and the genes responsible have been well characterized. However the correlation between the SMAD4 gene mutations with KRAS mutant status has not been explored by many studies so far. Here, in this study we aimed to investigate the role of SMAD4 gene aberrations in the pathogenesis of CRC in Kashmir valley and to correlate it with various clinicopathological variables and KRAS mutant genotype.

Methods: We examined the paired tumor and normal tissue specimens of 86 CRC patients for the occurrence of aberrations in MCR region of SMAD4 and exon 1 of KRAS by PCR-SSCP and/or PCR-Direct sequencing.

Results: The overall mutation rate of mutation cluster region (MCR) region of SMAD4 gene among 86 patients was 18.6\% (16 of 86). $68.75 \%$ (11/16) of the SMAD4 gene mutants were found to have mutations in KRAS gene as well. The association between the KRAS mutant genotype with SMAD4 mutants was found to be significant $(P=<0.05)$. Further more, we found a significant association of tumor location, tumor grade, node status, occupational exposure to pesticides and bleeding PR/Constipation with the mutation status of the SMAD4 gene $(P=<0.05)$.

Conclusion: Our study suggests that SMAD4 gene aberrations are the common event in CRC development but play a differential role in the progression of $C R C$ in higher tumor grade $(C+D)$ and its association with the KRAS mutant status suggest that these two molecules together are responsible for the progression of the tumor to higher/advanced stage.
\end{abstract}

\section{Background}

Colorectal carcinoma (CRC) is a common disease in both men and women worldwide. CRC is the third most common cause of cancer-related death in the western world and so is its incidence in Kashmir [1,2]. The majority of CRCs develop from benign pre-neoplastic lesions: the adenomatous polyps or adenomas. Progression from a benign adenoma to a malignant carcinoma passes through a series of well-defined histological stages, which is referred to as the adenoma-carcinoma sequence [3]. Two major mechanisms of genomic instability have been identified that give rise to colorectal carcinoma develop-

\footnotetext{
* Correspondence: vc.tmuk@gmail.com

1 Department of Immunology and Molecular Medicine, Sher-I-Kashmir Institute of Medical Sciences, Soura, Srinagar, Kashmir, India. 190011 + Contributed equally

Full list of author information is available at the end of the article
}

ment and progression: chromosomal instability (CIN) and microsatellite instability (MIN). CIN is associated with a series of genetic changes that involve the activation of oncogenes as KRAS and inactivation of tumor suppressor genes as TP53, SMAD4/DPC4 and APC, while as MIN is associated with mutations in DNA mismatch repair (MMR) genes which affect DNA replication in repetitive sequences (microsatellites), resulting in an accumulation of frameshift mutations in genes that contain microsatellites [4-6].

The discovery of human homologues of the Drosophila Mad gene, called SMAD genes [7], has been a milestone for understanding the genetics of the CRC whether of familial origin or sporadic, that has opened the Pandora's Box for both developmental and cancer biologists. Mutations in two Smad family member genes - SMAD4 (also 
known as $M A D H 4, D P C 4 \& J I P$ ) and SMAD2 (also known $M A D R 2$, and $h M A D-2)$ have been identified in human cancers and more importantly with high frequency in pancreatic and CRCs [8]. This raises the possibility that one or more of these genes can act as tumor suppressors as well as developmental regulators. Approximately 50\% of pancreatic carcinomas, $20 \%$ of colon carcinomas, and $10 \%$ of lung cancers exhibit mutations in SMAD4, and mutations in SMAD2 have been found in 7\% of colorectal and lung cancers $[7,9]$.

SMAD4 gene is located on the long arm (q) of chromosome 18 at band 21.1. The gene encompasses $49.5 \mathrm{~kb}$ of DNA with 13 exons, the first two constituting 5'-UTR as they do not code for any protein. SMAD4 mRNA transcript constitutes 3220 nucleotides [10]. The protein of SMAD4 gene - Smad4 belongs to the Darfwin family of proteins which harbors two conserved amino- and carboxyl-terminal domains known as MH1 and MH2, respectively. Smad4 in the basal state is found mostly as a homo-oligomer, most likely a trimer. It is ubiquitously expressed within the human body. Smad4 is an intracellular mediator of TGF- $\beta$ family and activin type 1 receptor. Smad4 mediate TGF- $\beta$ signaling to regulate cell growth and differentiation. TGF- $\beta$ stimulation leads to phosphorylation and activation of Smad2 and Smad3, which form complexes with Smad4 that accumulate in the nucleus and regulate transcription of target genes. By interacting with DNA-binding proteins, Smad complexes then positively or negatively regulate the transcription of target genes [11-13].

Considering the important role of SMAD4 gene in the colorectal carcinogenesis, we devised our study analyze the role of SMAD4 gene aberrations in the pathogenesis of CRC in Kashmir valley and correlate it with various clinicopathological variables and KRAS mutant genotype.

\section{Methods}

\section{Patients and specimens}

Out of 124 patients who were diagnosed with colorectal carcinoma (CRC) by clinicians using either sigmoidscopy or colonoscopy and confirmed by MRI, a total of $86 \mathrm{col}-$ orectal cancer tissue specimens comprising tumor tissues and the corresponding adjacent normal tissues as controls were collected for analysis in this study. All samples were surgically resected and were collected fresh at the Department of Surgery of Sher-I-Kashmir Institute of Medical Sciences, Srinagar, Kashmir. Tissue samples were divided into two parts; one part was sent to histopathological diagnosis and other half was stored at $-70^{\circ} \mathrm{C}$ for molecular investigations. Only histopathologically confirmed cases were included for molecular analysis. The specimens (both tumor and adjacent normal) were snapfrozen at $-70^{\circ} \mathrm{C}$ immediately until further analysis. No follow up of the CRC patients was carried out after the cura- tive surgery. Written informed consent was obtained from all the subjects (and or guardian) included in the study was taken on pre-designed questionnaire (Available on request) and was carried out in accordance with the principles of the Helsinki Declaration. The study protocol was approved by the Research Ethics Committee of SherI-Kashmir Institute of Medical Sciences, Kashmir.

\section{DNA isolation}

Genomic DNA was extracted from blood and tissue samples (previously stored in $-70^{\circ} \mathrm{C}$ ) of colorectal cancer patients using DNA Extraction Kit II (Zymo Research, USA) for examining mutations in MCR region (exon 2, 811) of SMAD4 gene and exon 1 of KRAS gene. The tissue for DNA extraction from tumor sample was chosen by experienced pathologist and was ascertained to contain more than $90 \%$ of the tumor cells.

\section{PCR-SSCP analysis}

The SMAD4 and KRAS gene analysis was done on all the extracted DNA samples. The MCR region of SMAD4 gene comprising of exons 2, 8, 9, 10 and 11 and exon 1 of KRAS were amplified using specific oligonucleotide primers [Table 1] [Additional file 1]. PCR was performed in a $25 \mu \mathrm{l}$ total volume reaction mixture containing $50 \mathrm{ng}$ of genomic DNA, $100 \mathrm{ng}$ of each primer, $100 \mu \mathrm{M}$ of each dNTP, $1.5 \mathrm{mM} \mathrm{MgCl}_{2}, 10 \times$ of Taq buffer and $1 \mathrm{U}$ of Taq DNA polymerase (Genie, India). The conditions of PCR were as: initial denaturation at $95^{\circ} \mathrm{C}$ for $5 \mathrm{~min}, 35$ cycles of denaturation at $95^{\circ} \mathrm{C}$, annealing at $\mathrm{X}^{\circ} \mathrm{C}$ [Table 1] and extension at $72^{\circ} \mathrm{C}$, for 30 seconds each and final extension at $72^{\circ} \mathrm{C}$ for $7 \mathrm{~min}$ in Biorad $i$ cycler. The PCR products were run on $2 \%$ agarose gel and analyzed under UV illuminator.

SSCP analysis of PCR product was carried out on 6\% non-denaturing Polyacrylamide gel (PAG) utilizing either non-radioactive silver staining or radioactive procedures [14-16] [Additional file 1]. In non-radioactive SSCP analysis, PCR products mixed in denaturing buffer ( $95 \%$ formamide, $10 \mathrm{mM} \mathrm{NaOH}, 0.05 \%$ xylene-cyanol $\mathrm{FF}$ and $0.05 \%$ bromophenol blue) in 1:1 ratio were heat denatured at $95^{\circ} \mathrm{C}$ for $5 \mathrm{~min}$, immediately cooled on ice for 20 min, $6 \mu \mathrm{l}$ of which were loaded on 6\% PAG and eletrophoresed in $0.5 \times$ Tris-borate EDTA buffer at $\pm 17^{\circ} \mathrm{C}$ at 4 W constant power for 18-22 h. Gels were then silver stained. In radioactive SSCP analysis, radio labeled PCR products (using $\alpha 32$-pCTP) mixed in denaturing loading buffer (95\% formamide, $20 \mathrm{mM}$ EDTA, 0.05\% xylenecyanol $\mathrm{FF}$ and $0.05 \%$ (bromophenol blue) in 1:10 ratio were heat denatured at $95^{\circ} \mathrm{C}$ for $5 \mathrm{~min}, 3 \mu \mathrm{l}$ of which were loaded on 6\% PAG and electrophoresed at $4 \mathrm{~W}$ in $0.5 \times$ Tris-borate EDTA buffer at $\pm 17^{\circ} \mathrm{C}$ for $18-22 \mathrm{~h}$. Gel was then transferred onto $3 \mathrm{~mm}$ Whatmann paper, covered with saran wrap and dried in vacuum drier at $90^{\circ} \mathrm{C}$ for 1 
Table 1: Specific primers for SMAD4 mutational analysis

\begin{tabular}{|c|c|c|c|}
\hline Gene/Exon & Sequence & Amplicon Size (bp) & $T_{m}\left({ }^{\circ} \mathrm{C}\right)$ \\
\hline SMAD4/Ex 2 & $\begin{array}{l}\text { F 5'-TTC TAGGTG GCT GGT CGG AA-3' } \\
\text { R 5'-CAG GTG ATA CAA CTC GTT CG-3' }\end{array}$ & 175 & 56 \\
\hline SMAD4/Ex 8 & $\begin{array}{l}\text { F 5'-TTT CTC ATG GGA GGA TGT TC-3' } \\
\text { R 5'-CAA TाT TाT AAA GTA ACT ATC TGA C-3' }\end{array}$ & 264 & 57 \\
\hline SMAD4/Ex 9 & $\begin{array}{l}\text { F 5'- TAT TAA GCA TGC TAT ACA ATC TG -3' } \\
\text { R 5'- CTT CCA CCC AGA TTT CAA TTC -3' }\end{array}$ & 332 & 58 \\
\hline SMAD4/Ex 10 & $\begin{array}{l}\text { F 5'-GAA TाT TCT TTA TGA ACT CAT AG-3' } \\
\text { R 5'-TाT AAA AAA GAA TGA AAA GCA TAC-3' }\end{array}$ & 213 & 57 \\
\hline SMAD4/Ex 11 & $\begin{array}{l}\text { F 5'-CTG ATG TCT TCC AAA CTC TTT TCT G-3' } \\
\text { R 5'-TGT ATT TTG TAG TCC ACC ATC-3' }\end{array}$ & 299 & 57 \\
\hline KRAS/Ex1 & $\begin{array}{l}\text { F: 5'-CTG CTG AAA ATG ACT GAA TA-3' } \\
\text { R: 5'-ATG GTC CTG CAC CAG TAA TA-3' }\end{array}$ & 162 & 48 \\
\hline
\end{tabular}

h. The saran wrap was then replaced by X-ray film and kept at $-70^{\circ} \mathrm{C}$ for $48 \mathrm{~h}$.

The mobility shift in DNA bands were visualized by developing the X-ray film in a developer. Purified PCR products of the samples showing mobility shift on SSCP analysis and randomly chosen samples were used for direct DNA sequencing.

\section{Direct Sequencing}

PCR amplicons of the tumor samples and from randomly chosen normal samples were first purified by DNA recovery kit (Zymo Research, USA) and then used for direct DNA sequencing. DNA sequencing was carried out at MACROGEN INC, Korea. To minimize the sequencing artifacts by PCR, amplicons from at least two different PCRs were sequenced using forward and reverse primers.

\section{Statistical Analysis}

All statistical analysis was performed using PASW, Version 18 (IBM, USA). Pearson's chi-square two-proportion test was used to evaluate the hypothesis of equal distribution of molecular alterations in different clinic-pathological variables. A chi-square probability (P values) of 0.05 or less was considered to be statistically significant. No adjustment was made for performing multiple tests.

\section{Results}

Out of 86 confirmed cases of CRC, 38 were of Duke's $A+B$ Stage and 48 were of Stage C+D. All of them presented constipation and bleeding per rectum as their chief complaint. Further more, out of 86 confirmed cases of CRC, 81 cases were sporadic, 4 were FAP and one case was Lynch Syndrome. All but one case were adenocarcinoma and only one was squamous cell carcinoma (SCC) of basal cell type. 37 cases were females and 49 males, 59 rural and 27 urban, 36 cases had carcinoma in colon and 50 in rectum and 55 were smokers and 31 non smokers [Table 2].

The overall mutation rate of mutation cluster region (MCR) of SMAD4 gene among 86 patients was 18.6\% (16 of 86) [Table 2, Figure 1 \&2]. 68.75\% (11/16) of the $S M A D 4$ gene mutants were found to have mutations in $K R A S$ gene as well, the data (of KRAS mutations only) has been previously declared by our lab in two studies $[14,15]$ by Sameer et al, 2009. Out of 11 KRAS mutants seven had mutations that has been reported already by our lab. In addition to those we also found two new novel mutations in KRAS oncogene in new procured tumor tissue samples. One was the A:T > T:A transversion of in codon 16 resulting in the truncation (AAG > TAG; Lys > Stop) of Kras protein in two tumor tissues and second was the C:T $>\mathrm{T}$ :C transition at codon 19 leading to change of leucine to phenaylalanine (CTT > TTT) in two tumor tissues [Table 2, Figures 3 \&4]. In Total 21 of 86 (24.4\%) tumor tissues had mutant KRAS gene out of these 21, 11 (52.4\%) were $S M A D 4$ gene mutants [Table $3 \& 4$ ]. There were 9 (56.25\%) tumors which had both KRAS activating mutations as well as $S M A D 4$ single point mutations. Furthermore, in case of advanced/higher grade tumors $(\mathrm{C}+\mathrm{D}=$ 48), KRAS gene mutations was found $15(31.25 \%)$ and SMAD4 gene was found to be mutated in $14(29.2 \%)$ tumors. Also, 9 (18.75\%) of C + D grade tumors had 
Table 2: Nature of SMAD4 MCR region mutations in 86 colorectal carcinoma patients from Kashmir valley

\begin{tabular}{|c|c|c|c|c|c|c|c|c|c|c|c|c|c|c|}
\hline Patient ID & Age/Sex ${ }^{a}$ & Dwelling $b$ & $\begin{array}{l}\text { Duke's } \\
\text { Stagec }\end{array}$ & $\begin{array}{l}\text { Smoking } \\
\text { Status }^{d}\end{array}$ & $\begin{array}{l}\text { Node } \\
\text { Statuse }\end{array}$ & Sitef & Natureg & $\begin{array}{l}\text { Pesticide } \\
\text { Exposure }\end{array}$ & $\begin{array}{l}\text { SMAD } \\
4 \text { Exon }\end{array}$ & Mutation ${ }^{h}$ & $\begin{array}{l}\text { Amino Acid } \\
\text { Change }\end{array}$ & $\begin{array}{l}\text { Affected } \\
\text { Codon }\end{array}$ & Effect ${ }^{i}$ & $\begin{array}{l}\text { KRAS Status/ } \\
\text { Affected Codon }\end{array}$ \\
\hline $\mathrm{X} 01$ & $55 / \mathrm{M}$ & $\mathrm{R}$ & A & NSk & $\mathrm{N}$ & $\mathrm{C}$ & LS & $Y$ & 2 & $\mathrm{IGT}>\mathrm{CGT}$ & Cys $>$ Arg & 115 & MS & $\mathrm{M} ; 12 \mathrm{Gly}>\mathrm{Asp}$ \\
\hline X06 & $28 / \mathrm{M}$ & $\mathrm{R}$ & C & Sk & $\mathrm{Y}$ & $\mathrm{R}$ & $S$ & $Y$ & 8 & $\underline{\mathrm{CGC}}>\mathrm{AGC}$ & Arg $>$ Ser & 361 & MS & W \\
\hline $\mathrm{X} 12$ & $65 / F$ & $\mathrm{R}$ & $C$ & Sk & $\mathrm{Y}$ & C & $\mathrm{S}$ & $Y$ & 10 & $\underline{C A G}>$ TAG & Gln $>$ Stop & 442 & NS & w \\
\hline $\mathrm{X} 16$ & $62 / F$ & U & $\mathrm{C}$ & Sk & $\mathrm{Y}$ & C & $\mathrm{S}$ & $\mathrm{N}$ & 8 & $C \underline{G C}>C A C$ & Arg $>$ His & 361 & MS & w \\
\hline $\mathrm{X} 17$ & $67 / F$ & $\mathrm{R}$ & $\mathrm{D}$ & Sk & $\mathrm{Y}$ & $\mathrm{R}$ & $\mathrm{S}$ & $Y$ & 8 & $\Pi T I>T G$ & Phe $>$ Leu & 362 & MS & M; 12 Gly > Asp \\
\hline X30 & $44 / F$ & $\mathrm{R}$ & D & Sk & $Y$ & $C$ & $\mathrm{~s}$ & $Y$ & 8 & $\mathrm{IGT}>A \mathrm{GT}$ & Cys $>$ Ser & 363 & MS & M; 12 Gly > Asp \\
\hline X31 & $64 / M$ & $\mathrm{R}$ & C & Sk & $\mathrm{Y}$ & C & FAP & $Y$ & 8 & $\mathrm{G} \underline{\mathrm{GT}}>\mathrm{GAT}$ & Gly $>$ Asp & 341 & MS & w \\
\hline $\mathrm{X} 43$ & $80 / \mathrm{F}$ & U & D & Sk & $Y$ & $\mathrm{R}$ & $S$ & $Y$ & 10 & $\mathrm{GCI}>\mathrm{GCC}$ & Ala $>$ Ala & 456 & $\mathrm{~s}$ & w \\
\hline $\mathrm{X} 47$ & $60 / \mathrm{F}$ & $\mathrm{R}$ & B & Sk & $\mathrm{N}$ & $\mathrm{C}$ & $\mathrm{S}$ & $\mathrm{Y}$ & 11 & $\mathrm{AAAGGC}>\mathrm{AATTGC}$ & Lys $>$ Asn; Gly $>$ Cys & $507 / 8$ & MS & M; 13 Gly > Cys \\
\hline $\mathrm{X} 51$ & $58 / \mathrm{M}$ & $\mathrm{R}$ & C & Sk & $\mathrm{Y}$ & C & $\mathrm{S}$ & $Y$ & 11 & $\underline{\mathrm{GGC}}>A \mathrm{AGC}$ & Gly $>$ Ser & 508 & MS & M; 12 Gly > Ser \\
\hline$X 56$ & $45 / \mathrm{M}$ & U & $\mathrm{D}$ & Sk & $\mathrm{Y}$ & $\mathrm{R}$ & $\mathrm{s}$ & $Y$ & 9 & $\underline{\mathrm{TGG}}>\mathrm{GGG}$ & Trp $>$ Gly & 419 & MS & M; 19 Leu > Phe \\
\hline $\mathrm{X} 57$ & $40 / \mathrm{M}$ & $\mathrm{R}$ & $\mathrm{D}$ & Sk & Y & C & FAP & $\mathrm{N}$ & 9 & $\underline{A G A C A G A G>A G A G}$ & Deletion & $415 / 16<<$ & FS & M; 16 Lys > Stop \\
\hline $\mathrm{X} 65$ & $43 / M$ & $\mathrm{R}$ & $C$ & NSk & $\mathrm{Y}$ & C & $S$ & $Y$ & 8 & $\mathrm{C} \underline{\mathrm{GC}}>\mathrm{CAC}$ & Arg $>$ His & 361 & MS & M; 19 Leu > Phe \\
\hline $\mathrm{X} 75$ & $55 / F$ & $\mathrm{R}$ & C & NSk & $\mathrm{Y}$ & C & $\mathrm{S}$ & Y & 11 & $\underline{A A A}>C A A$ & Lys $>$ Gln & 507 & MS & M; 13 Gly > Arg \\
\hline $\mathrm{X} 85$ & $38 / \mathrm{M}$ & U & $\mathrm{C}$ & Sk & $Y$ & C & $\mathrm{S}$ & $\mathrm{N}$ & 9 & $\mathrm{~A} \underline{\mathrm{G}} \mathrm{A}>\mathrm{A} A \mathrm{~A}$ & Arg $>$ Lys & 415 & MS & M; 16 Lys > Stop \\
\hline $\mathrm{X} 86$ & $60 / M$ & $\mathrm{R}$ & $D$ & Sk & $\mathrm{Y}$ & $C$ & $\mathrm{~s}$ & $Y$ & 10 & $\underline{\mathrm{CGA}}>\mathrm{TGA}$ & Arg $>$ Stop & 445 & NS & $\mathrm{M} ; 12 \mathrm{Gly}>$ Ala \\
\hline
\end{tabular}

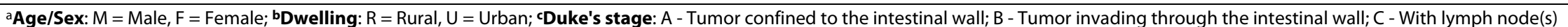
involvement; D - With distant metastasis; dSmoking Status: Sk: Smokers; NSk: Non Smokers; eNode Status: $\mathrm{N}=$ Negative, $\mathrm{P}=$ Positive; ${ }^{\mathrm{f} S i t e}$ of tumor: $\mathrm{C}=\mathrm{Colon}, \mathrm{R}=$ Rectum; 9Nature of tumor: $\mathrm{S}$ : Sporadic; LS: Lynch Syndrome; FAP: Familial Adenomatous Polyposis; hMutation: Mutated or inserted nucleotide underlined; hMutation Effect: MS: Missense mutation; NS: Nonsense mutation; S: Silent mutation; FS: Frameshift mutation. 
Table 3: Clinico-epidemiological variables of the 86 colorectal carcinoma patients versus 16 mutant phenotypes of SMAD4 gene

\begin{tabular}{|c|c|c|c|}
\hline Variable & Total $\mathbf{N}=86$ & Mutants $\mathrm{M}=16(18.6 \%)$ & Pvalue* \\
\hline \multicolumn{4}{|l|}{ Age group } \\
\hline$\leq 60$ & $52(60.5 \%)$ & $11(21.2 \%)$ & NS \\
\hline$>60$ & $34(39.5 \%)$ & $5(14.7 \%)$ & \\
\hline \multicolumn{4}{|l|}{ Gender } \\
\hline Female & $37(43.0 \%)$ & $7(18.9 \%)$ & NS \\
\hline Male & $49(67.0 \%)$ & $9(18.4 \%)$ & \\
\hline \multicolumn{4}{|l|}{ Dwelling } \\
\hline Rural & $59(68.6 \%)$ & $12(20.3 \%)$ & NS \\
\hline Urban & $27(31.4 \%)$ & $4(14.8 \%)$ & \\
\hline \multicolumn{4}{|c|}{ Tumor location } \\
\hline Colon & $36(41.9 \%)$ & $12(33.3 \%)$ & $<0.01$ \\
\hline Rectum & $50(58.1 \%)$ & $4(8.0 \%$ & \\
\hline \multicolumn{4}{|l|}{ Nodal status } \\
\hline Involved & $48(55.8 \%)$ & $14(29.2 \%)$ & $<0.01$ \\
\hline Not Involved & $38(44.2 \%)$ & $2(5.3 \%)$ & \\
\hline \multicolumn{4}{|l|}{ Tumor grade } \\
\hline$A+B$ & $38(44.2 \%)$ & $2(5.3 \%)$ & $<0.01$ \\
\hline$C+D$ & $48(55.8 \%)$ & $14(29.2 \%)$ & \\
\hline \multicolumn{4}{|c|}{ Smoking status } \\
\hline Ever & $55(64.0 \%)$ & $13(23.6 \%)$ & NS \\
\hline Never & $31(36.0 \%)$ & $3(9.6 \%)$ & \\
\hline \multicolumn{4}{|c|}{ Bleeding PR/Constipation } \\
\hline Yes & $60(69.8 \%)$ & $15(25.0 \%)$ & $<0.01$ \\
\hline No & $26(30.2 \%)$ & $1(3.8 \%)$ & \\
\hline \multicolumn{4}{|c|}{ Pesticide Exposure } \\
\hline Ever & $53(61.6 \%)$ & $13(24.5 \%)$ & $<0.05$ \\
\hline Never & $33(38.4 \%)$ & $3(9.1 \%)$ & \\
\hline \multicolumn{4}{|l|}{ KRAS Status } \\
\hline Wild-type & $65(75.6 \%)$ & $5(7.7 \%)$ & $<0.01$ \\
\hline Mutated & $21(24.4 \%)$ & $11(52.4 \%)$ & \\
\hline
\end{tabular}

*Pearson's two proportion test 


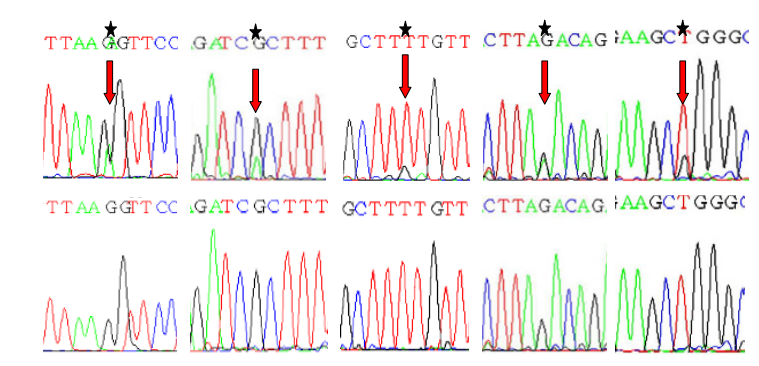

Figure 1 Partial nucleotide sequence representing the mutant (Above) and normal (Below) \{Shown by asterik and arrows\}, of MCR region of SMAD4 gene. 1A: Transition of $G>A$ at codon 341; $\mathrm{GGT}>\mathrm{GAT}$; Gly > Asp in Exon8 of SMAD4 gene. 1B: Transition of G > A at codon 361; CGC > CAC; Arg > His in Exon8 of SMAD4 gene. 1C: Transversion of $\mathrm{T}>\mathrm{G}$ at codon 362; TTT $>\pi \mathrm{TG}$; Phe $>$ Leu in Exon8 of SMAD4 gene. 1D: Transition of G > A at Codon 415; AGA > AAA; Arg > Lys in Exon9 of SMAD4 gene1E: Transversion of T > G at codon 419; TGG > GGG; Trp > Gly in Exon9 of SMAD4 gene

mutations in both KRAS as well as SMAD4 gene as compared to only $2(5.2 \%)$ of $\mathrm{A}+\mathrm{B}$ grade tumors [Table $4 \& 5$ ]. The mutant status of KRAS and SMAD4 gene was found to be significantly associated with the higher tumor grade $(\mathrm{C}+\mathrm{D})(\mathrm{P}$ value $=0.03)$.

Analysis of the mutation spectrum of MCR region of SMAD4 gene revealed 16 mutations in total. There were twelve missense mutations, two nonsense mutations, one silent mutation and one frameshift mutation - including nine transitions and four transversions. The frame shift mutation was observed in codons 415/416 (exon 9) due to deletion of AGACA pentamer [Table 2, Figure 2]. Among the transistions, G:A > A:G substitutions were most prevalent followed by $\mathrm{C}: \mathrm{T}>\mathrm{T}$ :C. The two nonsense mutations included, CAG > TAG transition leading to Gln > Stop at codon 442 and other CGA > TGA transition leading to Arg > Stop at codon 445, both occurred in exon 10 of SMAD4 gene [Table 2, Figure 1].

A number of salient and interesting features were found to be associated with the SMAD4 gene mutants, Among the 16 mutations seen, there were one $(6.25 \%)$ in exon 2 , six (37.5\%) in exon 8, three (18.75\%) each in exon 9, exon 10 , and exon 11 of MCR region of SMAD4 gene [Table 2]. Clearly the hot spot exon within the MCR region of the SMAD4 gene was exon 8 and within the exon 8 it was the codon 361 which was frequently aberrated due to muta-

\section{'ACTACT T ${ }^{\star}$ GAGAAGCT GGGCG}

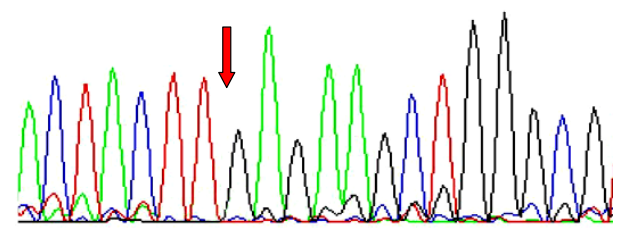

ACTACT T $\underline{A G A C A G A G A A G C T G G G C}$

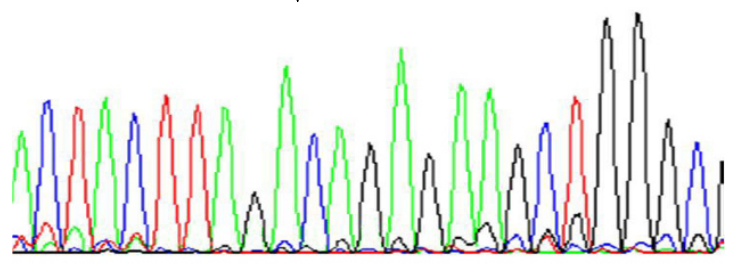

Figure 2 Partial nucleotide sequence representing the mutant (Above) and normal (Below) \{Shown by asterik and arrows\}, of Deletion of AGACA pentamer at codons 415/416 in Exon9 (MCR) of SMAD4 gene

tions. Out of 16 SMAD4 mutants two (X31 \& X57) were of FAP nature, one was LS (X01) and 13 remaining were of sporadic nature [Table 2].

Further more, we found a significant association of Tumor location, Nodal status and Bleeding PR/Constipation with the mutation status of the SMAD4 gene ( $\mathrm{P}=<$ 0.05). We also found association between the occupational exposure to pesticides with that of the mutant status of SMAD4 gene $(\mathrm{P}=<0.05)$ identifying it as a potential risk factor. There was also a significant association of the SMAD4 mutants with KRAS mutants [Table $3]$.

\section{Discussion}

Kashmir valley located in the northern division of India, surrounded by Himalayas has an unique ethnic population living in a temperate environmental conditions having distinctive food habits which play an overwhelming role in the development of GIT cancers over the genetic factors [17-19]. The food habits include consumption of sun-dried and smoked fish and meat, dried and pickled

Table 4: Correlation of SMAD4 gene status versus KRAS gene status

\begin{tabular}{|c|c|c|c|}
\hline \multicolumn{4}{|c|}{ SMAD4 Status } \\
\hline & Wild $\mathbf{N}=\mathbf{7 0}$ & Mutant $M=16$ & OR; P Value; Cl (95\%) \\
\hline \multicolumn{4}{|l|}{ KRAS Status } \\
\hline Wild; $\mathrm{n}=65$ & $60(92.3 \%)$ & $5(7.7 \%)$ & $0.07 ; \mathbf{0 . 0 0 0 0 3 ; 0 . 0 2 1 - 0 . 2 6}$ \\
\hline Mutant; $\mathrm{n}=21$ & $10(47.6 \%)$ & $11(52.4 \%)$ & \\
\hline
\end{tabular}




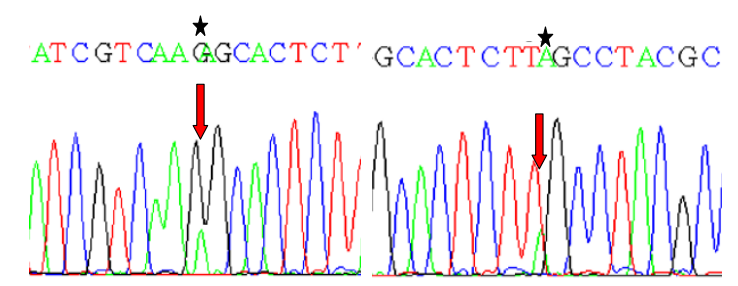

ATC GTCAAGGCACTCT TGCCTACGC

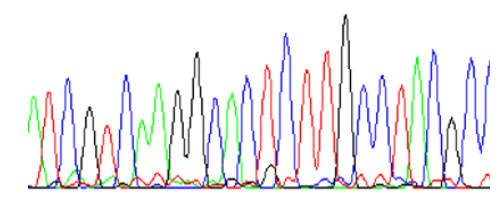

Figure 3 Partial nucleotide sequence (reverse) representing the mutant (A) and normal (B) \{Shown by asterik and arrows\}, of KRAS exon 1 gene. $3 A$ : Transition of $C>T$ at codon 19; $C T T>T T$; Leu $>$ Phe in Exon 1 of KRAS oncogene. 3B: Transversion of $\mathrm{A}>\mathrm{T}$ at codon 16; AAG $>$ TAG; Lys > Stop in Exon 1 of KRAS oncogene

vegetables, red chilly, Hakh (a leafy vegetable of Brassica family), hot noon chai (salted tea) and Hukka (water pipe) smoke [20]. As previously reported [21], the etiology and incidence of various GIT cancers in this population has been attributed to a probable exposure to nitroso compounds, amines and nitrates reported to be present in these local food stuffs.

Colorectal cancer being the commonest cancer, is the major cause of mortality and morbidity worldwide, there are nearly one million new cases of colorectal cancer diagnosed world-wide each year and half a million deaths [22]. The incidence of this malignancy shows consider-

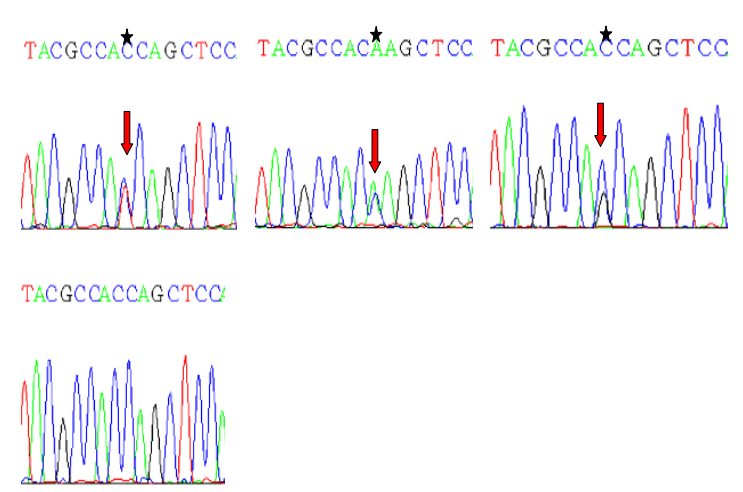

Figure 4 Partial nucleotide sequence (reverse) representing the mutant (A) and normal (B) \{Shown by asterik and arrows\}, of KRAS exon 1 gene. 4A: Transition of G > A at codon 12; to GGT > GAT; Gly > Asp in Exon 1 of KRAS oncogene. 4B: Transversion of $\mathrm{G}>\mathrm{T}$ at codon 12; GGT > TGT; Gly > Cys in Exon 1 of KRAS oncogene. 4C: Transversion of $\mathrm{G}>\mathrm{C}$ at codon 12; GGT > GCT; Gly > Ala in Exon 1 of KRAS oncogene able variation among racially or ethnically defined populations in multiracial/ethnic countries. Kashmir has been reported by now as a high-incidence area of GIT cancers $[19,20]$. Colorectal Cancer in Kashmir valley is the third most common GIT cancer after esophageal and gastric as per SKIMS Medical record registry, with almost over 124 cases reported by the end of year 2009 .

Among the most common genetic abnormalities in colorectal carcinomas, deletions in the long arm of chromosome 18 are the foremost one [3]. A number of different genes have been shown to be the target of these deletions, which include $A P C$ and SMAD2 and SMAD4 - the two genes of the TGF- $\beta$ signal transduction cascade [23]. TGF- $\beta$ signaling is an important regulator of proliferation, differentiation, and apoptosis with a key role in nontransformed human colon epithelium homeostasis $[24,25]$. The SMAD4 gene - already identified as a candidate tumor suppressor gene for pancreatic cancers [7] located at $18 \mathrm{q} 21.1$ in close proximity to $A P C$, has recently attracted considerable interest as a prime candidate target gene for the 18q deletions because of recent data linking mutations in this gene to sporadic and familial colorectal cancer $[26,27]$.

TGF- $\beta$ signaling regulates tumorigenesis and in human cancer its signaling pathways are often modified during tumor progression [28]. The growth inhibitory effect of TGF- $\beta$ signaling in epithelial cells explains its role as a tumor suppressor in carcinomas, although TGF- $\beta$ expression by tumor cells contributes to cancer progression as well $[29,30]$ thus unlike other signaling pathways it plays a dual role [31]. Smads are the key intracellular mediators of transcriptional responses to TGF- $\beta$ signaling, and among these Smad4 is the pivotal factor of the TGF- $\beta$ pathway as it functions as a key tumor suppressor [2426,29-31]. The role of Smad4 gene as an important tumor suppressor gene came out by the novel study of the allelotype loss in pancreatic adenocarcinoma [32]. This study showed that about $90 \%$ of these tumors show allelic loss of chromosome 18q. In the same year another study identified the genetic target of these allelic losses as the SMAD4/DPC4 gene (DPC-Deleted in Pancreatic Carcinoma, locus 4). The study analyzed 338 tumors, originating from 12 distinct anatomic sites, for alterations in the SMAD4/DPC4 gene. An alteration of the SMAD4/DPC4 gene sequence was identified in one of eight breast carcinomas and one of eight ovarian carcinomas. SMAD4/ $D P C 4$ was found to be homozygously deleted in about $30 \%$ of pancreatic carcinomas and inactivated by intragenic mutation in another $20 \%$ of the tumors. The tissue restriction of alterations in SMAD4/DPC4, as in many other tumor-suppressor genes, emphasizes the complexity of rate-limiting checkpoints in human tumorigenesis [33]. Most of Smad4 gene mutations in human cancer are missense, nonsense, and frameshift mutations 


\begin{tabular}{|c|c|c|c|c|}
\hline & \multicolumn{2}{|c|}{ Mutants } & \multirow[b]{2}{*}{$X^{2}, P$ value } & \multirow[b]{2}{*}{ Both $N=11$} \\
\hline & KRAS N = 21 & $S M A D 4 N=16$ & & \\
\hline \multicolumn{5}{|c|}{ Tumor Grade } \\
\hline$A+B=38$ & $6(28.6 \%)$ & $2(12.5 \%)$ & & $2(18.2 \%)$ \\
\hline \multirow[t]{2}{*}{$C+D=48$} & $15(71.4 \%)$ & $14(87.5 \%)$ & $6.63,0.03$ & $9(81.8 \%)$ \\
\hline & & & & $\mathrm{OR}=0.28 ; 95 \% \mathrm{Cl}=0.05-1.37$ \\
\hline
\end{tabular}

at the mad homology 2 region (MH2) which interfere with the homo-oligomer formation of Smad4 protein and hetero-oligomer formation between Smad4 and Smad2 proteins, resulting in disruption of TGF- $\beta$ signaling [12,26,33-35].

Our study was carried out to clarify the involvement of SMAD4 in the development and progression of colorectal carcinoma where it is reported to be mutated or deleted in about $20 \%$ of invasive cases [26] and the relationship between the mutant status of SMAD4 and KRAS genes. We found that 15 out of 16 mutations of SMAD4 gene occurred in C-terminal region of SMAD4 gene which codes for MH2 domain of Smad protein. These results are in conformation with the previous studies $[26,27,36]$ carried out on this gene. The MH2 domain of Smad4 protein is a multifunctional region that mediates differential association with a wide variety of proteins. Many of these interactions serve to provide specificity and selectivity to Smad function. The Smads exist as monomers and trimers, and through various studies it is clear that the $\mathrm{MH} 2$ domain is critical for mediating interactions in the oligomers [12]. The mutations in this region henceforth are deleterious to the overall interaction of Smad protein with itself and with other downstream proteins, thereby affecting the signal transduction of TGF- $\beta$ pathway and hence hampering normal colonic mucosal cell development and differentiation. Furthermore, in a recent study by Zhang et al, 2009 on transgenic mice [37] it was found beyond doubt that wild smad4 protein played an important anti-metastatic role in the development and progression of CRC. It was also found in this seminal study that loss of Smad4 in MC38 cells plays an important role in increasing the tumorigenic and metastatic potential of these cells as the loss of smad4 protein appears to switch TGF- $\beta$ from a tumor suppressor to a tumor promoter pathway.

Another salient feature of the mutations found in this study was the deletion of AGACA pentamer in exon 9 of the SMAD4 gene in one tumor tissue from a Familial Adenomatous Polyposis case [Figure 2]. This affected codon is $415 / 16$ of the SMAD4 gene reflecting its effect on $\mathrm{MH} 2$ domain of Smad4 protein. Similar type of deletion has also been reported previously by Miyaki et al,
1999 in Familial Adenomatous Polyposis (FAP) tumors within the same region of the SMAD4 gene [26]. Also, this tumor tissue was found to be KRAS mutant. The two nonsense mutations found in this study - one affecting codon 442 (Gln > Stop) and other codon 445 (Arg > Stop) occurred in exon 10 of SMAD4 gene. Both of these mutations lead to the synthesis of truncated Smad4 protein devoid of oligomerisation properties. One of these mutant tumors was found to be KRAS mutant at codon 12 (Gly > Ala) as well [Figure $3 \& 4$ ].

We also assessed the relationship between the TGF- $\beta$ pathway and MAP Kinase pathway via SMAD4 and KRAS proteins. We found that 21 out of $86(24.4 \%)$ tumors were KRAS mutants, and out of 16 SMAD4 mutants 11 (52.4\%) were KRAS mutants also. The cross talk mechanism between these two pathways has been experimented upon and conceptualized previously [38]. Cross-talk between $R A S$ and TGF- $\beta$ signaling has been reported to play important roles in various physiological and pathological processes, and $R A S$ signal has been reported to regulate TGF- $\beta$ signaling both positively and negatively [39]. RAS transformation in lung, intestinal, liver, pancreas, and mammary epithelial cells has been reported to confer resistance to growth inhibition by TGF- $\beta$ [40-42].

We found a significant association between the mutant statuses of the SMAD4 gene with that of the KRAS gene, thereby suggesting that similar mechanisms in our population where a cross talk between the MAP Kinase and TGF- $\beta$ pathways might play a role in the development of CRC to advanced stage cumulatively $[38,39,43]$ as we found $29(60.4 \%)$ of higher grade tumors $(C+D)$ were mutants for either of the two genes (KRAS and SMAD4) [Table 5]. Also, we found that $9 / 11$ (81.8\%) of the both gene mutants belonged to $\mathrm{C}+\mathrm{D}$ tumor grade category. This observation clearly suggested a link between these two important cell development controlling genes. In other words we can say that the tumor which has SMAD4 mutant status is also likely to have KRAS gene mutant status. Janda et al, 2002 [44] reported that hyperactivation of the Raf-MAP kinase pathway synergizes with TGF- $\beta$ signaling and induces epithelial-mesenchymal transition (EMT) and accelerates the tumorigenesis and metastasis of the otherwise normal cells. EMT has been 
found to be an important tread in the invasion and metastasis of cancer and TGF- $\beta$ prominently induces progression of cancer through EMT [45].

In a seminal study by Bardeesy et al, 2006 [46] on genetically engineered mice the impact of SMAD4 deficiency on the initiation, development and/or progression of pancreatic ductal adenocarcinoma (PDAC) was ascertained. It was observed that selective SMAD4 deletion in the pancreatic epithelium had no discernable impact on pancreatic development or physiology, but when combined with the activated $K R A S^{\mathrm{G} 12 \mathrm{D}}$ allele, SMAD4 deficiency enabled rapid progression of KRASG12D-initiated neoplasms. The study concluded that SMAD4 is a PDAC tumor suppressor, functioning to block the progression of $K R A S^{\mathrm{G} 12 \mathrm{D}}$-initiated neoplasm's. In another similar study by Izeradjene et al, 2007 [47] on various molecular aspects on invasive adenocarcinoma of pancreas, it was revealed that KRAS ${ }^{\mathrm{G} 12 \mathrm{D}}$ tumors had higher chances of developing the SMAD4 haplo-insufficiency, which in turn leads to invasiveness of the tumor.

As reported by many authors, the substitutions of codon 12 and 13 are predominant mutations in KRAS gene [48,49]. These amino-acid substitutions in KRAS alters its GTPase activity to a different extent and/or its ability to interact with its regulators, depending upon the substituted amino-acid residue [14]. KRAS ${ }^{\mathrm{G} 12 \mathrm{~V}}$ and $K R A S^{\mathrm{G} 12 \mathrm{R}}$ mutants are aggressive transforming phenotypes, while $K R A S^{\mathrm{G} 12 \mathrm{~S}}$ and $K R A S^{\mathrm{G} 12 \mathrm{D}}$ have less striking morphological effects [49]. In addition to the commonly reported activating mutation our analysis of KRAS gene also revealed a novel transversion of $\mathrm{A}>\mathrm{T}$ in codon 16 (Lys $>$ Stop) and an activating mutation in codon 19 (Leu to Phe). This study is the first to report these two novel mutations. Similar kind of mutations have been previously reported from this part of globe [50], where codons 15, 18, 20 and 30 of KRAS have been implicated in the tumorigenesis of CRC. Wang et al in their study showed that codon 15 Kras mutant protein has less GTPase activity than that of the wild-type Kras protein due to a lack of response to GAP induction owing to its less sensitivity to GAP.

Further more, we also found the SMAD4 mutant status associated with occupational exposure to pesticides, signifying that pesticides serves as the important risk factor in the development of CRC like other cancers [Table 3], as has been previously reported in various studies [5153]. This finding was also in tune with the study of Lee $e t$ $a l, 2007$ [54] in which various chemicals present in pesticides were found to be associated with the significant increased risk of colorectal cancer. In a seminal study by Blair et al, carried out on pesticide exposure to farmers indicated that farmers were more favorable to die of diseases including all causes combined, heart disease, as well as cancers of the lung, bladder, liver, colon, esophagus, rectum, and kidney. Following the criteria of Teitelbaum SL, 2002 [55], we also identified pesticide exposure as a potential risk factor for the development of CRC in Kashmir valley, since most of the cases reported in this part of globe are from rural areas and more importantly people who are directly or indirectly associated with agriculture as their main occupation and source of lively hood.

\section{Conclusion}

In this novel study, we found that SMAD4 gene aberrations are the common event in CRC development but play a differential role in the progression of CRC in higher tumor grade $(C+D)$. We have also observed a statistically significant association of SMAD4 gene aberrations with KRAS mutant status suggesting the involvement of at least two molecules in the advanced tumor grade in colorectal cancers; in other words, in case of high grade advanced tumor, aberration in more than one molecular gate keeper of several signal transduction pathways may be involved.

\section{Additional material}

Additional file 1 Representative gel pictures of all the amplicons of the SMAD4 MCR (exon 2, 8-11) and KRAS exon 1 and also SSCP gel picture of KRAS exon 1 amplicons.

\section{Competing interests}

The authors declare that they have no competing interests.

\section{Authors' contributions}

ASS conceived, designed and performed the lab work of the study. NAC procured and provided the tumor samples for the study. MZB and NSS assisted in the lab work of the study. ZAS, SA and MAS coordinated the study and revised the manuscript. All authors read and approved the final manuscript.

\section{Acknowledgements}

The authors gratefully acknowledge the Sher-I-Kashmir Institute of Medical Sciences, Kashmir for providing funds for this research work. We also acknowledge the statistical help of Dr. Bilal Ahmad Bhat of Department of Statistics, Sher-I-Kashmir University of Agricultural Sciences \& Technology, Kashmir. We would like to express our gratitude to Dr. Meenu Balkhi of Department of Endocrinology and Dr. Nausheen Feroz and Adfar Yousuf of Department of Clinical Biochemistry for their technical support and providing useful tips in the laboratory work of this study. The authors also gratefully acknowledge the technical staff of especially Miss Roohi and Mr. Reyaz of Department of General Surgery for helping in the procurement of tumor tissue samples from Operation Theater. We also thank the anonymous pathologists of Department of Pathology for the histopathological assessment of the tumor tissues.

\section{Author Details}

'Department of Immunology and Molecular Medicine, Sher-I-Kashmir Institute of Medical Sciences, Soura, Srinagar, Kashmir, India. 190011, 2Department of Clinical Biochemistry, Sher-I-Kashmir Institute of Medical Sciences, Soura, Srinagar, Kashmir, India. 190011, 3Department of General Surgery, Sher-IKashmir Institute of Medical Sciences, Soura, Srinagar, Kashmir, India. 190011 and ${ }^{4}$ Department of Biotechnology, Kashmir University, Hazratbal, Srinagar, Kashmir, India. 190006

Received: 6 November 2009 Accepted: 17 June 2010

Published: 17 June 2010 


\section{References}

1. Calvert PM, Frucht H: The genetics of CRC. Ann Intern Med 2002, 137:603-612.

2. Kemp Z, Thirlwell C, Sieber O, Silver A, Tomlinson I: An update on the genetics of CRC. Hum Mol Gene 2004, 13(2):R177-R185.

3. Vogelstein B, Fearon ER, Hamilton SR, Kern SE, Preisinger AC, Leppert M, Nakamura Y, White R, Smits AM, Bos JL: Genetic alterations during colorectal-tumor development. N Engl J Med 1988, 319:525-532.

4. Boland CR, Thibodeau SN, Hamilton SR, Sidransky D, Eshleman JR, Burt RW, Meltzer SJ, Rodriguez-Bigas MA, Fodde R, Ranzani GN, Srivastava S: A National Cancer Institute Workshop on Microsatellite Instability for cancer detection and familial predisposition: development of international criteria for the determination of microsatellite instability in CRC. Cancer Res 1998, 58:5248-5257.

5. Conlin A, Smith G, Carey FA, Wolf CR, Steele RJ: The prognostic significance of K-ras, p53, and APC mutations in colorectal carcinoma. Gut 2005, 54:1283-1286.

6. Hsieh JS, Lin SR, Chang MY, Chen FM, Lu CY, Huang TJ, Huang YS, Huang CJ, Wang JY: APC, K-ras, and p53 gene mutations in CRC patients: correlation to clinicopathologic features and postoperative surveillance. Am.Surg 2005, 71:336-343.

7. Hahn SA, Schutte M, Hoque ATMS, Moskaluk CA, de Costa LT, Rozenblum E, Weinstein CL, Fischer A, Yeo CJ, Hruban RH, Kern SE: DPC4, a candidate tumor suppressor gene at human chromosome 18q21.1. Science 1996, 271:350-353.

8. Riggins GJ, Thiagalingam S, Rozenblum E, Weinstein CL, Kern SE, Hamilton SR, Willson JK, Markowitz SD, Kinzler KW, Vogelstein B: Mad-related genes in the human. Nat Genet 1996, 13:347-349.

9. Riggins GJ, Kinzler KW, Vogeistein B, Thiagalingam S: Frequency of smad gene mutations in human cancers. Cancer Res 1997, 57:2578-2580.

10. Saffroy $R$, Lemoine A, Debuire B: SMAD4 (mothers against decapentaplegic homolog 4 (Drosophila). 2004 [http:// AtlasGeneticsOncology.org/Genes/SMAD4ID371.html]. Atlas Genet Cytogenet Oncol Haematol

11. Attisano L, Wrana JL: Smads as transcriptional co-modulators. Curr Opin Cell Biol 2000, 12:235-243.

12. Attisano L, Lee-Hoeflich ST: The Smads. Genome Biology 2001, 2:reviews3010.1-30108.

13. Shi Y: Structural insights on Smad function in TGF $\beta$ signaling. Bioessays 2001, 23:223-232

14. Sameer AS, Chowdhri NA, Abdullah S, Shah ZA, Siddiqi MA: Mutation pattern of K-ras gene in colorectal cancer patients of Kashmir: A report. Indian J cancer 2009, 3:219-225.

15. Sameer AS, Rehman S, Pandith AA, Syeed N, Shah ZA, Chowdhri NA, Wani $K A$, Siddiqi MA: Molecular gate keepers succumb to gene aberrations in colorectal cancer in Kashmiri population, revealing a high incidence area. Saudi J Gastroentero/ 2009, 15:244-252.

16. Hussain I, ul Rehman S, Afroze D, et al.: Mutational spectrum of conserved regions of TP53 and PTEN genes in Kangri cancer (of the skin) in the Kashmiri population. Mutat Res 2009, 676:5-10.

17. Shah A, Jan GM: Pattern of cancer at Srinagar (Kashmir). Indian J Pathol Microbiol 1990, 33:118-23.

18. Murtaza I, Mushtaq D, Margoob MA, Dutt A, Wani NA, Ahmad I, Bhat ML: A study on $\mathrm{p} 53$ gene alterations in esophageal squamous cell carcinoma and their correlation to common dietary risk factors among population of the Kashmir valley. World J Gastroenterol 2006, 12:4033-4037

19. Salam I, Hussain S, Mir MM, Dar NA, Abdullah S, Siddiqi MA, Lone RA Zargar SA, Sharma S, Hedau S, Basir SB, Bharti AC, Das BA: Aberrant promoter methylation and reduced expression of $\mathrm{p} 16$ gene in esophageal squamous cell carcinoma from Kashmir valley: a high-risk area. Mol Cell Biochem 2009, 332:51-58.

20. Mir MM, Dar NA, Gochhait S, Zargar SA, Ahangar AG, Bamezai RN: p53 Mutation profile of squamous cell carcinomas of the esophagus in Kashmir (India): a high-incidence area. Int J Cancer 2005, 116:62-68.

21. Siddiqi M, Kumar R, Fazili Z, Spiegelhalder B, Preussmann R: Increased exposure to dietary amines and nitrate in a population at high risk of esophageal and gastric cancer in Kashmir (India). Carcinogenesis 1992 13:1331-5.

22. Boyle P, Elena M: Epidemiology of colorectal cancer. British Medical Bulletin 2002, 64:1-25.
23. Fearon ER, Cho KR, Nigro JM, et al.: Identification of a chromosome 18q gene that is altered in colorectal cancers. Science 1990, 247:49-56.

24. Elliott RL, Blobe GC: Role of transforming growth factor beta in human cancer. J of Clin Oncol 2005, 23:2078-2093.

25. Blobe GC, Schiemann WP, Lodish HF: Role of transforming growth factor $\beta$ in human disease. N Engl J Med 2000, 342:1350-1358.

26. Miyaki M, lijima $T$, Konishi $M$, et al:: Higher frequency of Smad4 gene mutation in human colorectal cancer with distant metastasis. Oncogene 1999, 18:3098-3103.

27. Koyama M, Ito M, Nagai H, Emi M, Moriyama Y: Inactivation of both alleles of the DPC4/SMAD4 gene in advanced colorectal cancers: identification of seven novel somatic mutations in tumors from Japanese patients. Mutat Res 1999, 406:71-77.

28. Bierie B, Moses HL: TGF- $\beta$ and cancer. Cytokine \& Growth Factor Reviews 2006, 17:29-40.

29. Derynck R, Zhang YE: Smad-dependent and Smad-independent pathways in TGF- $\beta$ family signaling. Nature 2003, 425:577-584

30. Massague J: TGF- $\beta$ signal transduction. Annu Rev Biochem 1998, 67:753-791

31. Yang G, Yang X: Smad4-mediated TGF- $\beta$ signaling in tumorigenesis. Int J Biol Sci 2010, 6:1-8.

32. Shi Y: Structural insights on Smad function in TGF- $\beta$ signaling. Bioessays 2001, 23:223-232.

33. Schutte $M$, Hruban $\mathrm{RH}$, Hedrick $\mathrm{L}$, et al:: DPC4 gene in various tumor types. Cancer Res 1996, 56:2527-2530.

34. Woodford-Richens KL, Rowan AJ, Poulsom R, et al:: Comprehensive analysis of SMAD4 mutations and protein expression in juvenile polyposis: evidence for a distinct genetic pathway and polyp morphology in SMAD4 mutation carriers. Am J Pathol 2001, 159:1293-1300.

35. Roth $\mathrm{S}$, Johansson $M$, Loukola A, Peltomaki $P$, Jarvinen $H$, Mecklin J-P, Aaltonen LA: Mutation analysis of SMAD2, SMAD3, and SMAD4 genes in hereditary non-polyposis CRC. J. Cell Sci 2003, 11:413-419.

36. lacobuzio-Donahue CA, , Song J, Parmiagiani G, Yeo CJ, Hruban RH, Kern $\mathrm{SE}$ : Missense mutations of MADH4: characterization of the mutational hot spot and functional consequences in human tumors. Clin. Cancer Res 2004, 10:1597-1604.

37. Zhang B, Halder SK, Kashikar ND, Cho YJ, Datta A, Gorden DL, Datta PK Antimetastatic Role of Smad4 Signaling in Colorectal Cancer. Gastroenterology 2009, 138:969-80. e1-3

38. Yue J, Frey RS, Mulder KM: Cross-talk between the Smad1 and Ras/MEK signaling pathways for TGF- $\beta$. Oncogene 1999, 18:2033-2037.

39. Pardali K, Moustakas A: Actions of TGF-beta as tumor suppressor and pro-metastatic factor in human cancer. Biochim Biophys Acta 2007, 1775:21-62.

40. Horiguchi K, Shirakihara T, Nakano A, Imamura T, Miyazono K, Saitoh M: Role of Ras signaling in the induction of snail by transforming growth factor-beta. J Biol Chem 2009, 284:245-53.

41. Schwarz LC, Gingras MC, Goldberg G, Greenberg AH, Wright JA: Loss of Growth Factor Dependence and Conversion of Transforming Growth Factor- $\aleph_{1}$ Inhibition to Stimulation in Metastatic H-ras-transformed Murine Fibroblasts. Cancer Res 1988, 48:6999-7003.

42. Filmus J, Kerbel RS: Development of resistance mechanisms to the growth-inhibitory effects of transforming growth factor-beta during tumor progression. Curr Opin Oncol 1993, 5:123-129.

43. Javelaud D, Mauviel A: Crosstalk mechanisms between the mitogenactivated protein kinase pathways and Smad signaling downstream of TGF-b: implications for carcinogenesis. Oncogene 2005, 24:5742-5750.

44. Janda E, Lehmann K, Killisch I, et al:: Ras and TGF- $\beta$ cooperatively regulate epithelial cell plasticity and metastasis: dissection of Ras signaling pathways. J Cell Biol 2002, 156:299-313.

45. Miyazono K: Transforming growth factor-b signaling in epithelialmesenchymal transition and progression of cancer. Proc Jpn Acad Ser B Phys Biol Sci 2009, 85:314-323.

46. Bardeesy N, Cheng K, Berger JH, et al.: Smad4 is dispensable for normal pancreas development yet critical in progression and tumor biology of pancreas cancer. Genes Dev 2006, 20:3130-3146.

47. Izeradjene K, Combs C, Best M, et al:: Kras(G12D) and Smad4/Dpc4 haploinsufficiency cooperate to induce mucinous cystic neoplasms and invasive adenocarcinoma of the pancreas. Cancer Cell 2007 11:229-43. 
48. Al-Mulla F, Going JJ, Sowden ET, Winter A, Pickford IR, Birnie GD: Heterogeneity of mutant versus wild--type in primary and metastatic colorectal carcinomas and association of codon 12 valine with early mortality. J Pathol 1998, 185:130-138.

49. Schubbert S, Shannon K, Bollag G: Hyperactive Ras in developmental disorders and. Cancer. Nat Rev Cancer 2007, 7:295-308.

50. Wang JY, Hsieh JS, Chen FM, et al:: High frequency of activated K-ras codon 15 mutant in colorectal carcinomas from Taiwanese patients. Int J Cancer 2003, 107:387-93.

51. Blair A, Zahm SH: Agricultural Exposures and Cancer. Environ Health Perspect 1995, 103(Suppl 8):205-208.

52. Ejaz S, Akram W, Lim CW, Lee JJ, Hussain I: Endocrine disrupting pesticides: a leading cause of cancer among rural people in Pakistan. Exp Oncol 2004, 26:98-105.

53. Spiewak R: Pesticides as a cause of occupational skin diseases in farmers. Ann Agric Environ Med 2001, 8:1-5.

54. Lee WJ, Sandler DP, Blair A, Samanic C, Cross AJ, Alavanja MC: Pesticide use and colorectal cancer risk in the Agricultural Health Study. Int J Cancer 2007, 121:339-46.

55. Teitelbaum SL: Questionnaire assessment of nonoccupational pesticide exposure in epidemiologic studies of cancer. J Exp Analy Environ Epidemiol 2002, 12:373-380.

\section{Pre-publication history}

The pre-publication history for this paper can be accessed here: http://www.biomedcentral.com/1471-2407/10/300/prepub

doi: 10.1186/1471-2407-10-300

Cite this article as: Sameer et al., SMAD4 - Molecular gladiator of the TGF-? signaling is trampled upon by mutational insufficiency in colorectal carcinoma of Kashmiri population: an analysis with relation to KRAS proto-oncogene BMC Cancer 2010, 10:300

\section{Submit your next manuscript to BioMed Central} and take full advantage of:

- Convenient online submission

- Thorough peer review

- No space constraints or color figure charges

- Immediate publication on acceptance

- Inclusion in PubMed, CAS, Scopus and Google Scholar

- Research which is freely available for redistribution

Submit your manuscript at www.biomedcentral.com/submit
C Biomed Central 